\title{
ANALYSIS OF TURKISH RESIDENTIAL CONSTRUCTION MARKET DYNAMICS FOR THE PERIODS OF 2010-2015, 2015-2019, AND PROJECTIONS FOR THE FUTURE
}

\author{
Mehmet Emre ÇAMLIBEL (D1) ${ }^{1}$ Natalija LEPKOVA (D2 2*, Çağdaş AYGÜN ${ }^{3}$ \\ ${ }^{1,2}$ Department of Construction Management and Real Estate, Faculty of Civil Engineering, Vilnius Gediminas \\ Technical University, Vilnius, Lithuania \\ ${ }^{3}$ Re-pie Asset Management, Istanbul, Turkey
}

Received 30 April 2020; accepted 18 August 2020

\begin{abstract}
The Turkish residential market supported by macro-economic developments is of great importance for the country's economy and the construction industry. The main purpose of this study is to analyze the Turkish residential construction market dynamics, especially in terms of price-cost and supply-demand regimes and conduct future projections.

For this purpose, analysis of construction cost and residential price indexes, total and mortgaged residential sales, and construction and occupancy permits were evaluated utilizing institutional data. In addition, positive and negative effects of the changes in the residential prices in the macro scale were examined. After, conducting the residential price and cost change analysis for between 2010-2023, future stock volume and residential market projections were carried out.

As a result of the analysis, we can divide the residential market into 3 periods: positive development period between 2010 and 2015, the recession period from 2015 to 2019, and the period after 2020. In the projection, depending on the supply contraction and the results of demand changes, price and cost increases, the current residential stock volume will reach its lowest level by 2023. Following this, the last period is expected to reach a more balanced residential market shaped by need-based purchases rather than individual investments.
\end{abstract}

Keywords: residential market, construction, construction cost index, price index, residential price bubble.

\section{Introduction}

Construction is generally known as an activity with many specific features which differs from other industries; construction activities have always been closely connected with the social and economic activities of every country. The construction sector contributes directly to the GDP of any country by entering the national accounts as a component of investment (Lepkova et al., 2017). The specific character of construction industry ranges wide: from design solutions, technological, technical and economic solutions, decision-making methods, through to organizational solutions and efficient management. Construction industry in general has always been a subject of interest not only for businessmen, but for different institutions as well (Kapliński, 2018). The real estate market is characterized by relatively low frequency of transactions (2-3 deals in a lifetime for most people in case of private residential properties), which increases the amount of transaction costs in comparison with fast moving consumer goods
(Manzhynski et al., 2018). Residential property prices are closely related to the main economic variables and play an important role in the whole economy. For example, it has been found that a 10 percent increase in housing wealth leads to a 1.1 percent increase in national consumption (Milunovich, 2020). Asset price bubbles can have significant adverse effects on the real economy (Caraiani et al., 2020).

The Turkish residential market, supported by macroeconomic developments, especially since the mid-2000s, was of great importance for the country's economy and the construction industry. Monitoring historical development of indicators such as price-cost and supply-demand regimes is important in evaluating the residential market that shows a significant contribution to the growth of Turkey's economy.

The main purpose of this study is to analyze the Turkish residential construction market dynamics, especially in

*Corresponding author. E-mail: natalija.lepkova@vgtu.lt 
terms of price-cost and supply-demand regimes for three different time periods (2010-2015, 2015-2019 and later) and conduct future projections based on construction costs. In the first part of the study, analysis of construction cost and residential price indexes, total and mortgaged residential sales, and construction and occupancy permits were evaluated utilizing institutional data such as TurkStat, CBRT, and GYODER.

In the second part of the study, including the new economic program of the country for the three-year period starting from 2020, residential price and cost change analysis were conducted for between 2010-2023. Also, depending on the current stock and stock absorption rate, future stock volume and residential market projections were carried out.

\section{Residential price indexes}

The real estate price index can guide national macroeconomic regulations and plays an important role in the direction of the development of the real estate market, attracting much attention (Liu et al., 2014).

The role of the residential market, which is among the reasons for the 2008 global financial crisis, has increased the importance of monitoring the price movements in the residential sector. The residential price index reflects the developments in the market and gives information about its connection with macroeconomic variables. For this reason, the Central Bank of the Republic of Turkey (CBRT) has filled an important gap by preparing the index for residential prices in Turkey since 2010 (Kılınç \& Tunç, 2014). One of these indexes, the Residential Price Index (RPI), consists of the prices for all the houses offered for sale regardless of construction year (CBRT, 2017). The real prices for the houses sold are obtained from the prices in the valuation reports issued in banks that provide mortgage loans. In calculation of the New Residential Price Index (NRPI), which is another type of price index, valuation reports of the built year, and previous year are used (CBRT, 2020c). Turkey is ranked 15th among 56 countries, with an annual price growth rate of $6.3 \%$ according to Knight Frank Global House Price Index for Q3-2018Q3-2019 (Cagli, 2019; Knight Frank, 2019).

Based on the data of the Central bank, the change of residential prices in Turkey's economy is shown in Figure 1.

Since the end of 2015, the growth rate of the increases in residential prices begins to slow down and then decreases gradually. One of the reasons that explain this situation is the upward trend of the inflation rate in Turkey's economy since the beginning of 2016, and the doubledigit inflation effect since February of 2017 (Saraç, 2018). After the 2007-2008 crisis, rapid growth in the residential market with strengthened domestic demand in Turkey has experienced a revival. At the same time, the decrease in mortgage rates relatively reduced the cost pressure on the mortgage loan and the demand for the mortgage loan increased significantly (CBRT, 2020b).

The developments behind the rapid rise of residential price index especially after 2012 are as follows:

a) The decrease in mortgage and loan rates;

b) Increase in construction costs;

c) Increase in housing purchases for investment purposes by individuals;

d) Increase in GDP per capita increases the demand for assets, especially residential;

e) Turkey's demographic structure keeps housing demand alive;

f) In addition, it can be said that urban regeneration activities in Turkey create upward pressure on residential prices.

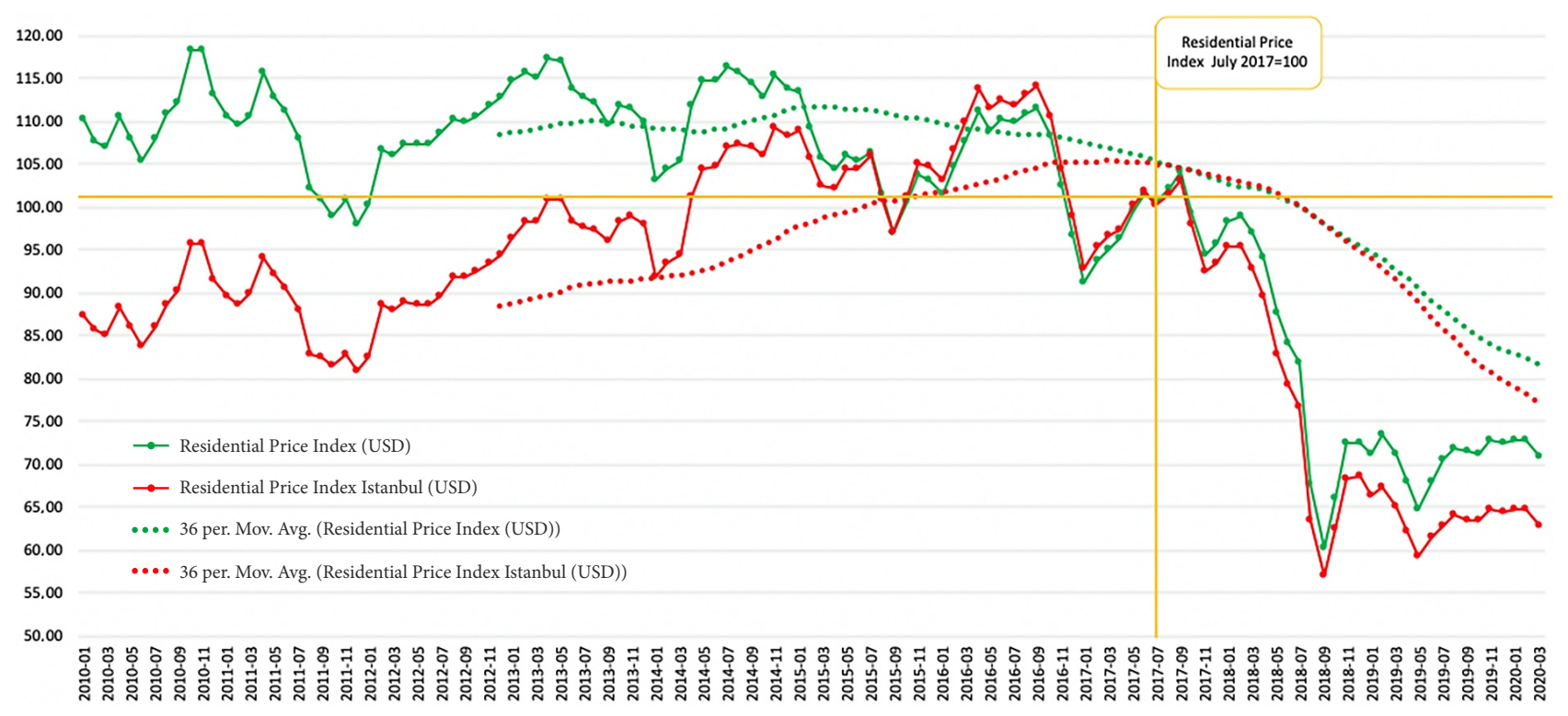

Figure 1. Residential price indexes of Turkey and Istanbul (USD) (created by authors based on on the data of the Central bank of Turkey) 


\section{Total and mortgaged residential sales}

Another indicator of the residential market developments in Turkey's economy is sales of residential units. Figure 2 shows the total and mortgaged residential unit sales and monthly mortgage rates between 2010-2020.

Although 607.098 residential units were sold in 2010, this number increased by $132.14 \%$ and reached 1.409 .314 by the end of 2017 (TurkStat, 2020c). The most important factors behind this increase are the mortgage interest rates and there is an increase in the demand to purchase residential units as a result of economic growth (CBRT, 2020a). In addition to this, large real estate companies initiated and spread throughout the residential sector with mortgage rate cuts and VAT deductions in recent years and caused a positive trend in sales in the residential market.

Major campaigns in the residential market made residential unit purchasing attractive, strengthening the demand for residential, and sales have increased especially with mortgaged residential sales (TurkStat, 2020d). However, due to the increase in the exchange rate in 2018, the increase in residential unit sales stopped.

\section{Construction cost}

Another variable in the housing market that has an impact on prices is the changes in construction costs index (CCI) and their impact on supply prices. The Construction Cost Index (CCI) is a weighted aggregate index of the prices of constant quantities of materials. This index provides changes occurring in costs on both short- and long terms in an attempt to get more accurate bids (Cao et al., 2015; Elfahham, 2019).

To determine the cost changes according to the period of the raw materials used in building construction, Construction Cost Index is published by the Turkish Statistical
Institute (TurkStat). Increasing costs in the residential sector both reduces the profitability of the investments and creates expectations for the future of residential prices (TurkStat, 2020b). Figure 3 shows the New Residential Price Index and cumulative change rate of the Construction Cost Index since 2017.

When the index with $2017=100$ base year is analyzed, it is seen that the costs in the construction sector were increased at a constant rate. In the first quarter of 2020, a $58 \%$ increase in construction costs was observed since 2017. Among the main reasons for this increase are; increase in inflation and interest rates, increases in imported raw material prices due to fluctuations in exchange rates, and increases in wage payments are effective (TurkStat, 2020e). Thus, the increase in construction costs can be counted among the reasons for the increase in housing prices.

\section{Construction and occupancy permits}

Another indicator showing the high increase in residential unit production is construction and occupancy permits. On the left axis of Figure 4, construction and occupancy permits are shown since 2002. On the right axis, it shows a change rate of these values compared to the previous year. An occupancy permit is a document that must be obtained for buildings that are completely or partially completed (TurkStat, 2020a). The construction permit is a document that must be obtained for the construction to start (TurkStat, 2020e). With this explanation, it can be said that the construction permit represents the housing demand and the occupancy permit represents the housing supply.

From Figure 4, it can be seen that both constructions permit, and occupancy permits were followed an increasing trend until 2017. Considering the construction per-

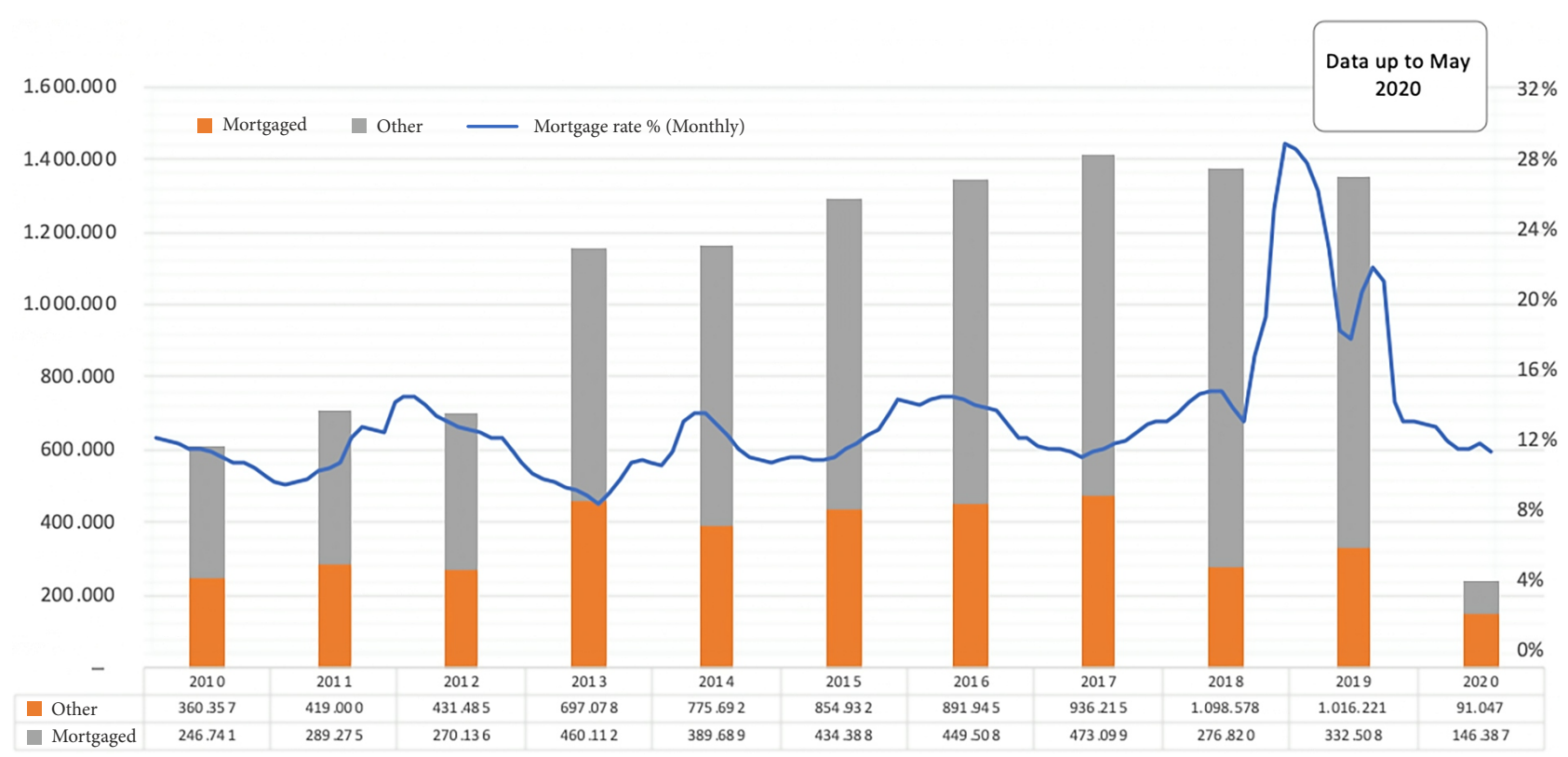

Figure 2. Total and mortgaged residential sales (created by authors based on on the data of the Central bank and TurkStat of Turkey) 
mit, total housing production was 161,491 in 2002, this number increased by $316 \%$ at the end of 2017 , reaching 833,517 . This ratio increased by $668 \%$ between $2002-2017$ and reached 1.405.447. The data for 2020 includes the first 3 months. The increase in construction costs and interest rates due to the devaluation in 2018 causes a decrease in residential unit sales. For this reason, developers are unable to reduce their residential unit stocks and because of many developing countries like Turkey have new project financing through the pre-sale model, which can be interpreted as the reasons for the decrease in permits.

\section{Current stock and stock absorption rate}

There is another data in the residential market called the stock absorption rate showing the supply-demand relationship in the Turkish economy. Stock Absorption Rate is prepared by REIDIN-GYODER based on the monthly sales data of the residential units (REIDIN, 2020). With this indicator, which is calculated on a square meter and unit basis, the sales speed of the branded residential units in the projects put on the market are monitored monthly. In Figure 5, the period between 2013-2020 with quarterly data shows the absorption rate of residential stock in Turkey.

It can be seen from Figure 5, the absorption rate of the residential unit stock in Turkey is a declining trend between the years 2013-2020. While the highest stock absorption rate in the third quarter of 2014 was $7.43 \%$, the lowest stock melting rate was seen in the second quarter of 2019 with $2 \%$. The stock absorption rate is an important indicator in terms of showing how long all the residential units in the market can be sold if there is no new supply in the residential market (GYODER, 2020). It reveals the mismatch between supply and demand in the housing market and the liveliness in the housing market.

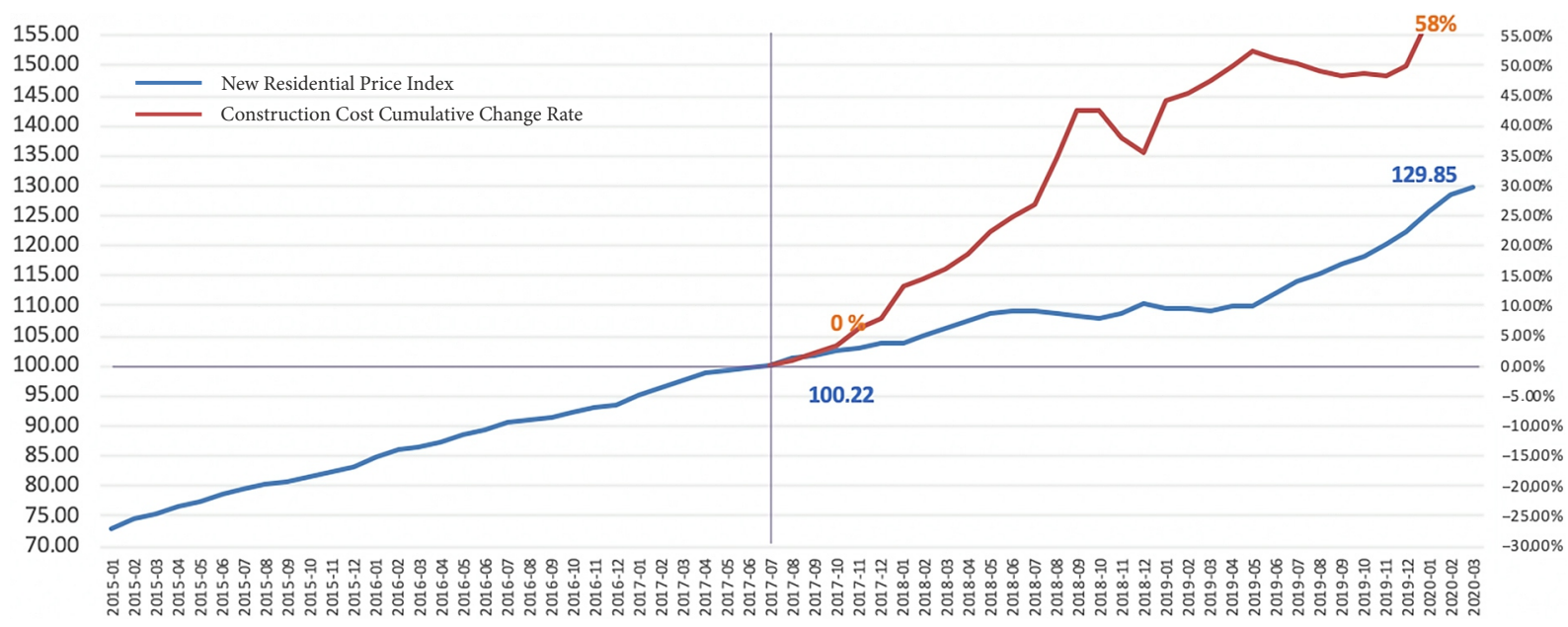

Figure 3. New residential price and construction cost index (2017:100) (created by authors based on on the data of the Central bank and TurkStat of Turkey)

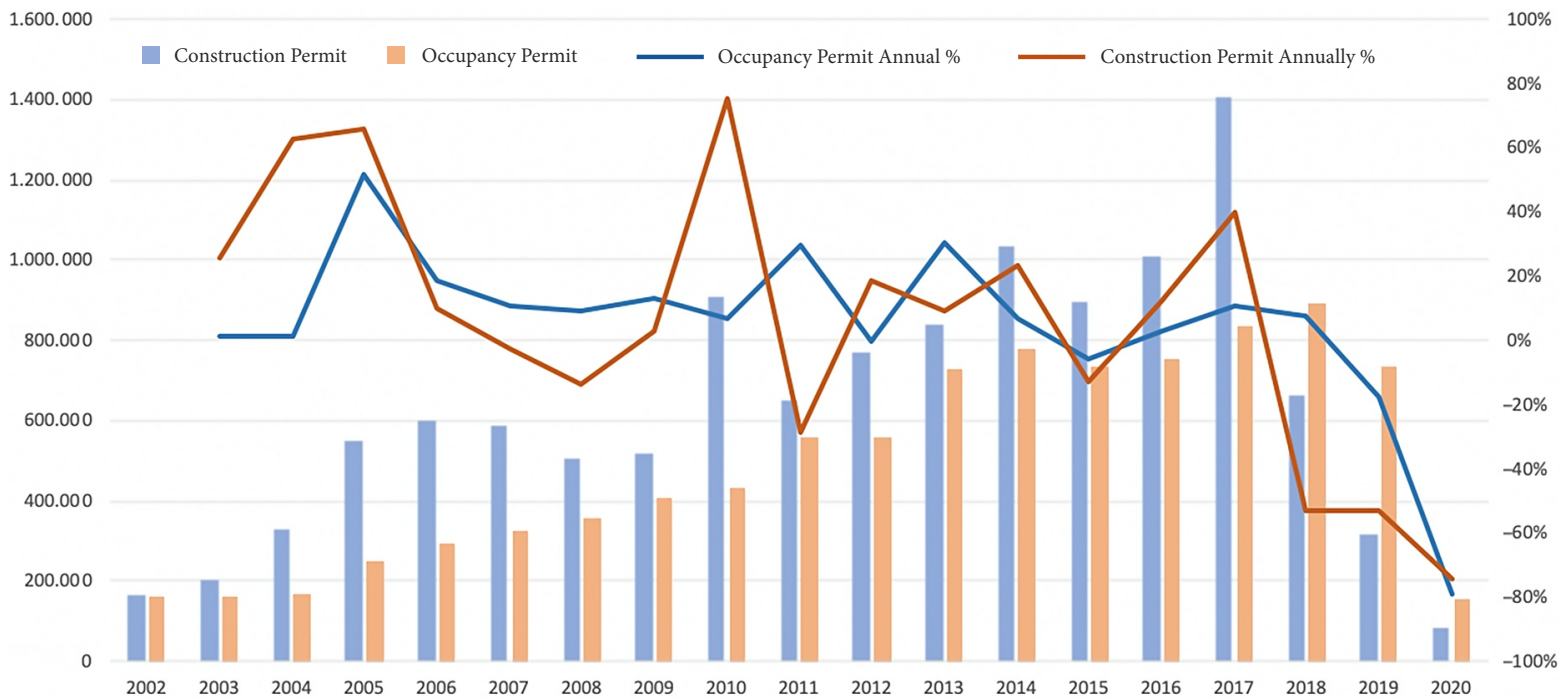

Figure 4. Number of construction and occupancy permits and change rates by years (created by authors based on on the data of the TurkStat) 


\section{Residential price and cost change analysis between 2010-2023}

The main purpose of this study is to analyze the Turkish residential construction market dynamics, especially in terms of price-cost and supply-demand regimes for three different time periods (2010-2015, 2015-2019 and later) and conduct future projections based on construction costs. In the first part of the study, analysis of construction cost and residential price indexes, total and mortgaged residential sales, and construction and occupancy permits were evaluated utilizing institutional data such as TurkStat, CBRT, and GYODER.
In Figure 6, including the New Economic Program (NEP) of the country for the three-year period starting from 2020, residential price and cost change analysis were conducted for between 2010-2023. Also, in the study, depending on the current stock and stock absorption rate, future stock volume, and residential market projections were carried out.

In order to follow the residential price growth in the analysis, it was estimated that the period with the highest profit + land margin was around $40 \%$ (Delta 1) in the light of the opinions received from professionals in the sector. After the new residential price index was fixed at 100 in 2010, the highest difference between the new resi-

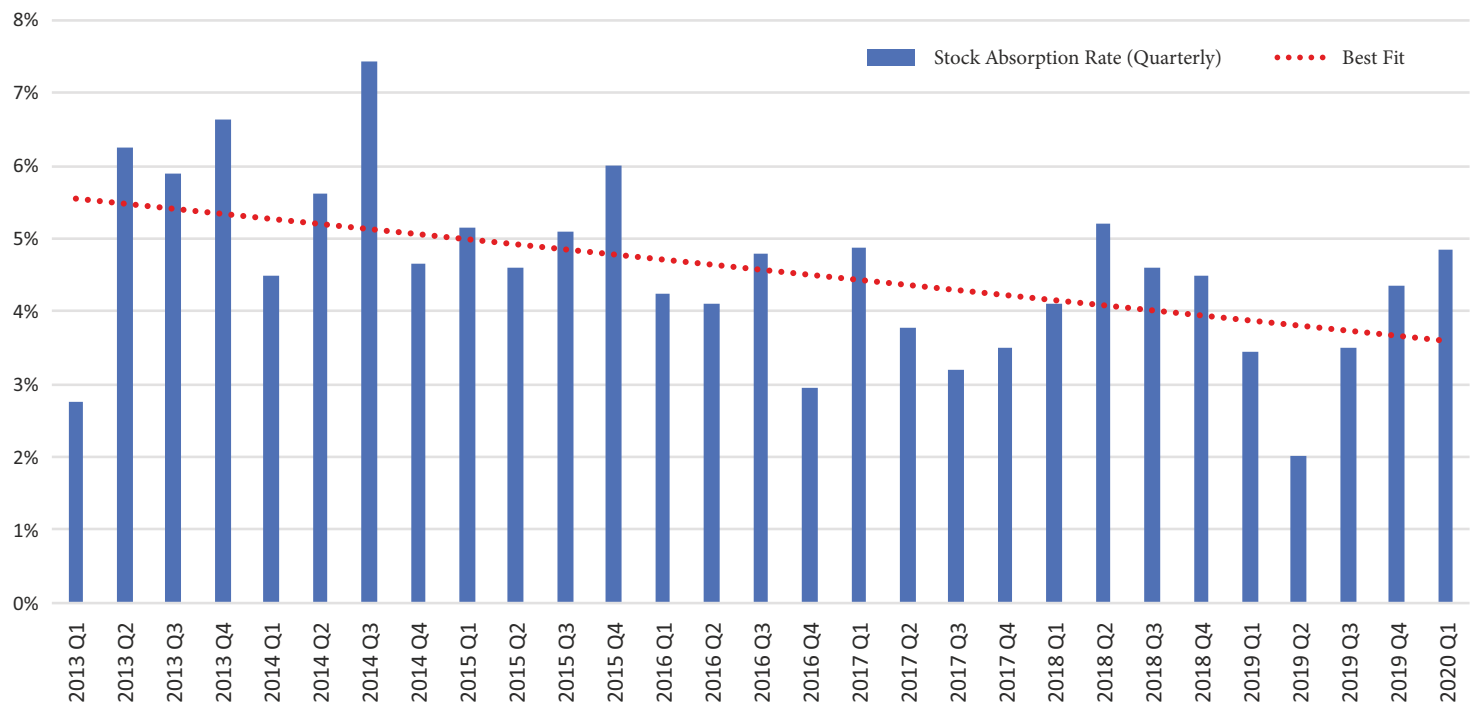

Figure 5. Stock absorption rate (\%)

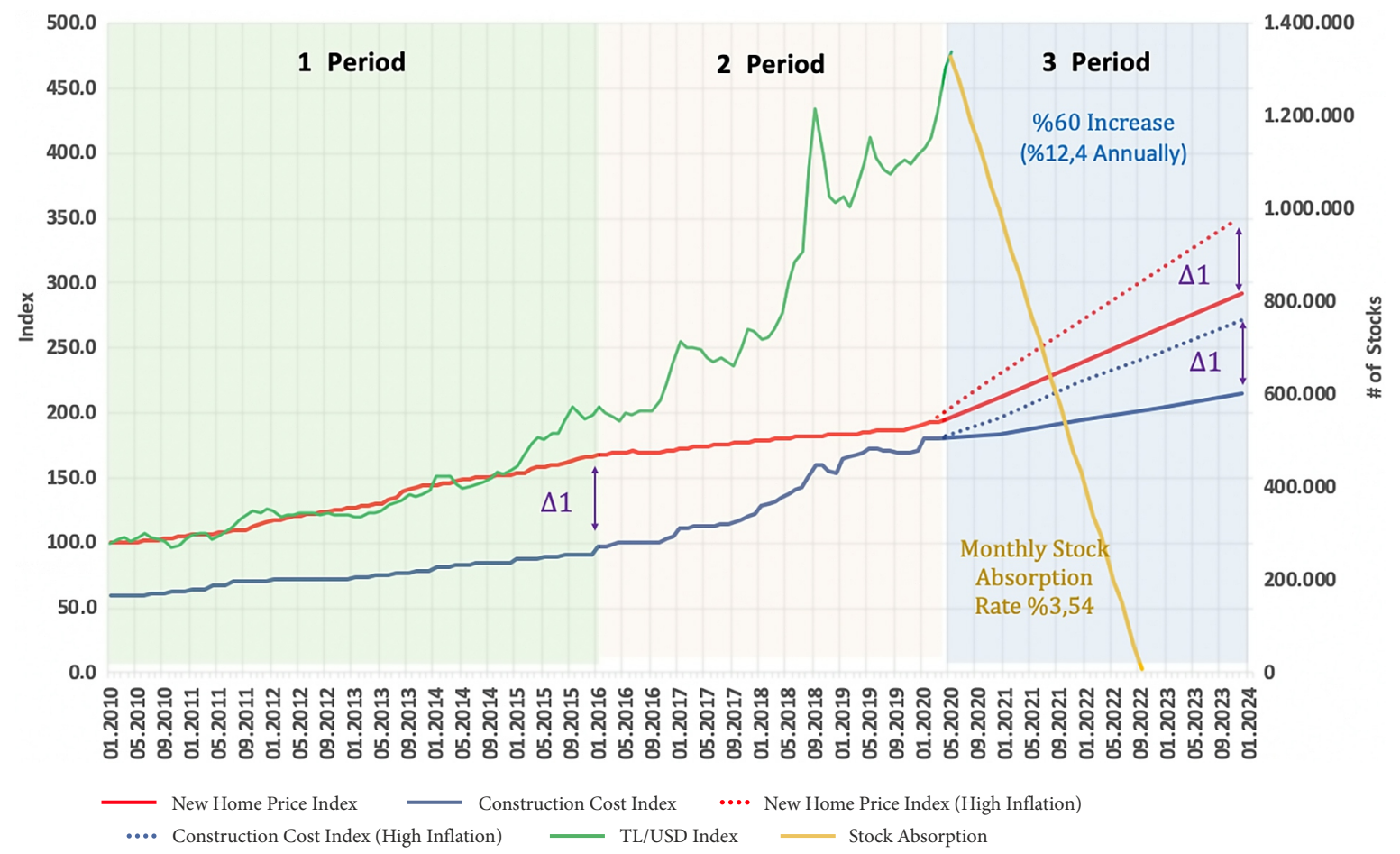

Figure 6. 2010-2023 analysis of residential price growth 
dential price index and the construction cost index was determined and the construction cost index was adjusted according to Delta 1 . In the past periods, it was observed that the construction cost index increased in accordance with the inflation, and the projection of the construction cost index was created according to the inflation stated in Turkey's new economic program from 2019 to 2022 and kept constant after 2022. The future new residential price index from 2020 to 2023 was created based on the prediction of the best profit + land margin (Delta 1) will be achieved in 2023, which was added top of the 2023 construction cost index. The stock volume stated in the chart was calculated as the difference between the total number of building permits per year and the total number of firsthand home sales between 2013-2019 by TurkStat data. In order to find out when the current stock will be depleted without considering the new supply, it was calculated by taking into account the monthly stock absorption rate of the last 1 year published in GYODER.

The assumptions made in the analysis are as follows:

1. Inflation was taken according to the Turkey's new economic program from 2019 to 2022 and kept constant after 2022 (Ministry of Treasury and Finance, 2019).

2. The Construction Cost Index is projected to increase in line with the inflation rate after 2019.

3. Profit + Land value margin is determined according to New Home Price Index and Construction Cost Index.

4. With decrease of supply and balanced demand, it is predicted that the cost + profit + land value ratios in 2023 will be the same ratio with 2016 .

5. Starting from April 2020 data announced in the GYODER bulletin, stock absorption rate $(3.54 \%$ per month) is calculated from the average of the monthly stock absorption rate values of the last 1 year and kept constant for the following months, and it is assumed that there will be no new supply.

6. Current stock volume is calculated as the difference between the total number of building permits per year and total number of first-hand home sales between 2013-2019 by TurkStat data.

7. If the future inflation ratios are higher than the targeted ratios in the NEP program, the analysis is shown in dotted lines. (2020: 14\%, 2021: 12\%, 2022: 10\%, 2023: 10\%)

\section{Analysis of the results}

\subsection{0-2015 positive period}

As a result of the analysis, in the period between 2010 to 2015 , the new residential price index and the construction cost index difference where we can call it as profit + land margin (Profitability at a level that will allow new supply) is in a reasonable market condition (Delta 1). This can be evaluated as a positive period due to the rapid growth in the residential sector, strengthening of domestic demand along with falling mortgage rates and also residential developers can actively develop residential projects.

\subsection{6-2020 contraction period}

In Figure 6, it is observed that after 2016, construction costs increased more than previous years due to the devaluation effect. However, in new residential prices, with the increase in interest rate caused by devaluation, a decrease was observed in the demand for residential units, and in parallel with this the increase of the residential prices was slowed down. It is observed that the difference between the residential price index and the construction cost index reached the lowest level in between 2019 and 2020 based on our best profit + land margin (Delta 1). Considering the land costs, we can interpret it as the "contraction" period where the developers priced their residential units below their value.

\subsection{0-2023 future projections}

In this section, a projection of the construction cost index up to 2023 was created based on the inflation targets announced in the New Economic Program. Then, the new residential price index was created, assuming that the difference between the new residential price index and the construction cost index in 2023 will be the highest profit + land margin at the end of 2015. In this scenario, it is foreseen that the construction cost index will increase by $19 \%$ as of the end of 2023 and the new residential price index will increase by $50 \%$ according to the targeted inflation value. If the actual inflation values are higher than those targeted by the NEP, the construction cost index is expected to increase by $50 \%$ as of the end of 2023 , and the new residential price index will increase by $80 \%$.

In residential stocks, $1,328,081$ existing stocks, which is the difference between the total number of constructions permits per year between 2013 and 2019, and the total number of first-hand housing sales, are expected to melt in September 2022, depending on the monthly average stock absorption rate published by GYODER. New residential units produced by the developers during the period are not included in the calculation.

\section{Conclusions}

The main purpose of this study is to analyze the Turkish residential construction market dynamics, especially in terms of price-cost and supply-demand regimes for three different time periods (2010-2015, 2015-2019 and later) and conduct future projections based on construction costs.

Since the end of 2015, the growth rate of the increases in residential prices started to slow down and then decreased gradually. The reasons are the upward trend in the inflation rate since the beginning of 2016 and the devaluation of the Turkish lira in 2018. These reasons led to an increase in the construction cost by $58 \%$ in the first quarter of 2020 since 2017. In parallel with this, with a decrease in residential unit sales and developers are unable to reduce their residential unit stocks because of many developing countries like Turkey have new project financing through the pre-sale model, there was a decrease in construction and occupancy permits. 
As a result of the analysis, in the period between 2010 to 2015 , the new residential price index and the construction cost index difference where we can call it as profit + land margin (Profitability at a level that will allow new supply) is in a reasonable market condition, which can be evaluated as a positive period. After 2016, due to the devaluation effect, it is observed that the difference between the residential price index and the construction cost index reached the lowest level in between 2019 and 2020 based on our best profit + land margin. Considering the land costs, we can interpret it as the "contraction" period where the developers priced their residential units below their value.

In the projection of the indexes formed according to the New Economic Program targets until 2023, it is predicted that the construction cost index will increase by $19 \%$ and the new residential price index will increase by $50 \%$ by the end of 2023 . If the targeted inflation values are higher, it is foreseen that the construction cost index will increase by $50 \%$ as of the end of 2023 , and the new residential price index will increase by $80 \%$. As for the residential unit stocks, 1,328,081 existing stocks are expected to melt in September 2022.

\section{Funding}

This research received no external funding.

\section{Author contributions}

Dr. Emre Çamlıbel conceived the study and was responsible for the design and development of the data analysis. Dr. Emre Çamlıbel, Dr. Natalija Lepkova and Çağdaş Aygün were responsible for data collection and analysis. Dr. Emre Çamlıbel and Dr. Natalija Lepkova were responsible for data interpretation. Çağdaş Aygün wrote the first draft of the article.

\section{Disclosure statement}

Authors do not have any competing financial, professional, or personal interests from other parties. The authors declare no conflict of interest.

\section{References}

Caraiani, P., Luiky, M. A., \& Wesselbaumz, D. (2020). Credit policy and asset price bubbles. Journal of Macroeconomics, 103229. https://doi.org/10.1016/j.jmacro.2020.103229

Cao, M. T., Cheng, M. Y., \& Wu, Y. W. (2015). Hybrid computational model for forecasting Taiwan construction cost index. Journal of Construction Engineering and Management, 141(4), 04014089.

https://doi.org/10.1061/(ASCE)CO.1943-7862.0000948

CBRT. (2017). Konut Fiyat Endeksi.

CBRT. (2020a). Exchange Rates. https://evds2.tcmb.gov.tr/index. php?/evds/serieMarket

CBRT. (2020b). Residential Property Price Index (RPPI) (2017= 100)(Monthly). https://evds2.tcmb.gov.tr/index.php?/evds/ serieMarket
CBRT. (2020c). Residential Property Price Index for New Dwellings $(N R P P I)(2017=100)$. https://evds2.tcmb.gov.tr/index. php?/evds/serieMarket

Cagli, E. C. (2019). Explosive behavior in the real estate market of Turkey. Borsa Istanbul Review, 19(3), 258-263.

https://doi.org/10.1016/j.bir.2018.10.002

Knight Frank. (2019). Global House Price Index. https://content. knightfrank.com/research/84/documents/en/global-houseprice-index-q3-2019-6859.pdf

Elfahham, Y. (2019). Estimation and prediction of construction cost index using neural networks, time series, and regression. Alexandria Engineering Journal, 58(2), 499-506. https://doi.org/10.1016/j.aej.2019.05.002

GYODER. (2020). GYODER Indicator, Turkish Real Estate Sector 2020 1st Quarter Report.

Kapliński, O. (2018). Innovative solutions in construction industry. Review of 2016-2018 events and trends. Engineering Structures and Technologies, 10(1), 27-33.

https://doi.org/10.3846/est.2018.1469

Kılınç, M., \& Tunç, C. (2014). Identification of monetary policy shocks in Turkey: A structural VAR approach (TCMB Working Paper 14/23). Türkiye Cumhuriyet Merkez Bankasi.

Lepkova, N., Vilutiene, T., Bełej, M., Putek-Szeląg, E., \& Źróbek, S. (2017). Comparative analysis of newly-built housing quality in Poland and Lithuania. Real Estate Management and Valuation, 25(4), 85-98. https://doi.org/10.1515/remav-2017-0032

Liu, J. E., Liu, H., Guo, W., \& Guo, Z. (2014). The establishment of Yanjiao's Real Estate Price Index. In ICCREM 2014: Smart Construction and Management in the Context of New Technology (pp. 1089-1096). ASCE.

https://doi.org/10.1061/9780784413777.129

Manzhynski, S., Źróbek, S., Batura, O., \& Zysk, E. (2018). Why the market value of residential premises and the costs of its purchase differ: The examples of Belarus and Poland. Land Use Policy, 71, 530-539.

https://doi.org/10.1016/j.landusepol.2017.11.012

Milunovich, G. (2020). Mapping out network connections between residential property markets. Economics Letters, 189, 109006. https://doi.org/10.1016/j.econlet.2020.109006

Ministry of Treasury and Finance. (2019). New Economy Program. https://ms.hmb.gov.tr/uploads/sites/2/2019/04/NewEconomy-Program-2019-2021.pdf

REIDIN. (2020). REIDIN-GYODER New Home Price Index: April 2020 Results.

Saraç, H. (2018). Konut Fiyat Endeksi Verilerinin Klasik Ayriştirma Ve Arima Yöntemi İle Tahmin Edilmesi [Forecasting housing price index data by classical decomposition and arima method]. Journal of International Social Research, 11(59), 1307-9581 (in Turkish).

https://doi.org/10.17719/jisr.2018.2717

TurkStat. (2020a). Completed or partially completed new buildings and additions by use of building, (new classification) (according to new classification and method) Since 2009. http://www. turkstat.gov.tr/PreTablo.do?alt_id=1056

TurkStat. (2020b). Construction cost index $(2015=100)$ and rate of change. http://www.turkstat.gov.tr/PreTablo.do?alt_id=1077

TurkStat. (2020c). House sales by districts and years. http://www. turkstat.gov.tr/PreTablo.do?alt_id=1056

TurkStat. (2020d). Mortgaged house sales in detail of first sale and second hand sale by provinces and years. http://www.turkstat. gov.tr/PreTablo.do?alt_id=1056

TurkStat. (2020e). New buildings and additions by use of building, since 2002. http://www.turkstat.gov.tr/PreTablo.do?alt_ id $=1056$ 